\title{
Total risk analyses for large dams in Kizilirmak basin, Turkey
}

\author{
H. Tosun ${ }^{1}$ and E. Seyrek ${ }^{2}$ \\ ${ }^{1}$ Eskişehir Osmangazi University, Faculty of Agriculture, Eskişehir, Turkey \\ ${ }^{2}$ Dumlupinar University, Civil Engineering Department, Kütahya, Turkey \\ Received: 12 January 2010 - Revised: 27 April 2010 - Accepted: 30 April 2010 - Published: 7 May 2010
}

\begin{abstract}
Dams located near urban areas have a high risk potential for life and property in downstream. Turkey is one of the most seismically active regions in the world and has at least 1200 large dams with different type. Major earthquakes with the potential of threatening life and property occur frequently here. Kizilirmak basin studied in this article is located in a seismically very active part of Turkey. The northern part of basin is structurally cut by a significant fault system. The shear zone, which is frequently jointed, fractured and faulted at the central part of basin increases total risk of dams within the zone. Consequently, there are so many large dams, which are located close to these faults in the basin. In this paper authors summarize the methods used for the analysis of total risk, discuss the seismic hazards of 36 large dams constructed in the Kizilirmak basin on the basis of the seismic activity of the dam site and their total risk as based on physical properties and the position in the basin. The seismic hazard analyses have indicated that peak ground acceleration changes within a wide range $(0.09 \mathrm{~g}$ and $0.45 \mathrm{~g})$ for the dam sites of basin. The total risk analyses depending on the seismic hazard rating of dam site and risk rating of the structure have concluded that 23 large dams have high-risk class in the basin.
\end{abstract}

\section{Introduction}

The total risk for dam structures primarily depends on the seismic hazard rating of dam site and the risk rating of the dam and appurtenant structures. The seismic hazard of a dam site can be based on the peak ground acceleration. This value derived from the defined design earthquake produces the main seismic loads. The risk rating of the dam should be based on the capacity of the reservoir, the height of the dam, the evacuation requirements, and the potential downstream

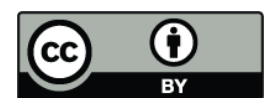

Correspondence to: $\mathrm{H}$. Tosun (htosun@ogu.edu.tr) damages. In general, the seismic and risk ratings are evaluated separately. Recently, these two factors were combined to define the total risk factor for dam structure.

ICOLD (1989) states that safety concerns for embankment dams subjected to earthquakes involve either the loss of stability due to a loss of strength in the embankment or foundation materials or excessive deformations such as slumping, settlement, cracking and planar or rotational slope failures. Safety concerns for concrete dams subjected to earthquakes should involve evaluation of the overall stability of the structure, such as verifying its ability to resist induced lateral forces and moments and preventing excessive cracking of the concrete. To obtain preliminary information about seismic parameters of the dam materials, the simplified procedures can be used for designing the embankment dams. If the materials used in the embankment are not susceptible to loss of strength, and the hazard and risk ratings are low, the simplified analyses are entirely sufficient to define the seismic evaluation parameters.

In Turkey, it is believed the fact that embankment dams, which are well compacted according to the specification, are suitable type for regions having high seismic activity. In general, strong ground shaking can result in the instability of the embankment and loss of strength at the foundations (Seed et al., 1969, 1975; Castro et al., 1985; Jansen, 1988). Active faults, which are very close to the foundation of dams, have the potential to cause damaging displacement of the structure. There are some examples of dams in Turkey which were damaged during the earthquakes occurred in past (Tosun, 2002).

The Kizilirmak basin is one of 26 basins as based on hydrological evaluation in Turkey. It covers a $78180 \mathrm{~km}^{2}$ area and has a water yield resources of $6.48 \mathrm{~km}^{3}$ per year. Kizilirmak river and its secondary branches once flow to west and then north to join Black sea (Fig. 1). The 52\% of the total basin area has been classified as cultivable land and most of them is feasibly irrigable. 36 dams have been designed for different purposes such as energy, irrigation, water supply

Published by Copernicus Publications on behalf of the European Geosciences Union. 


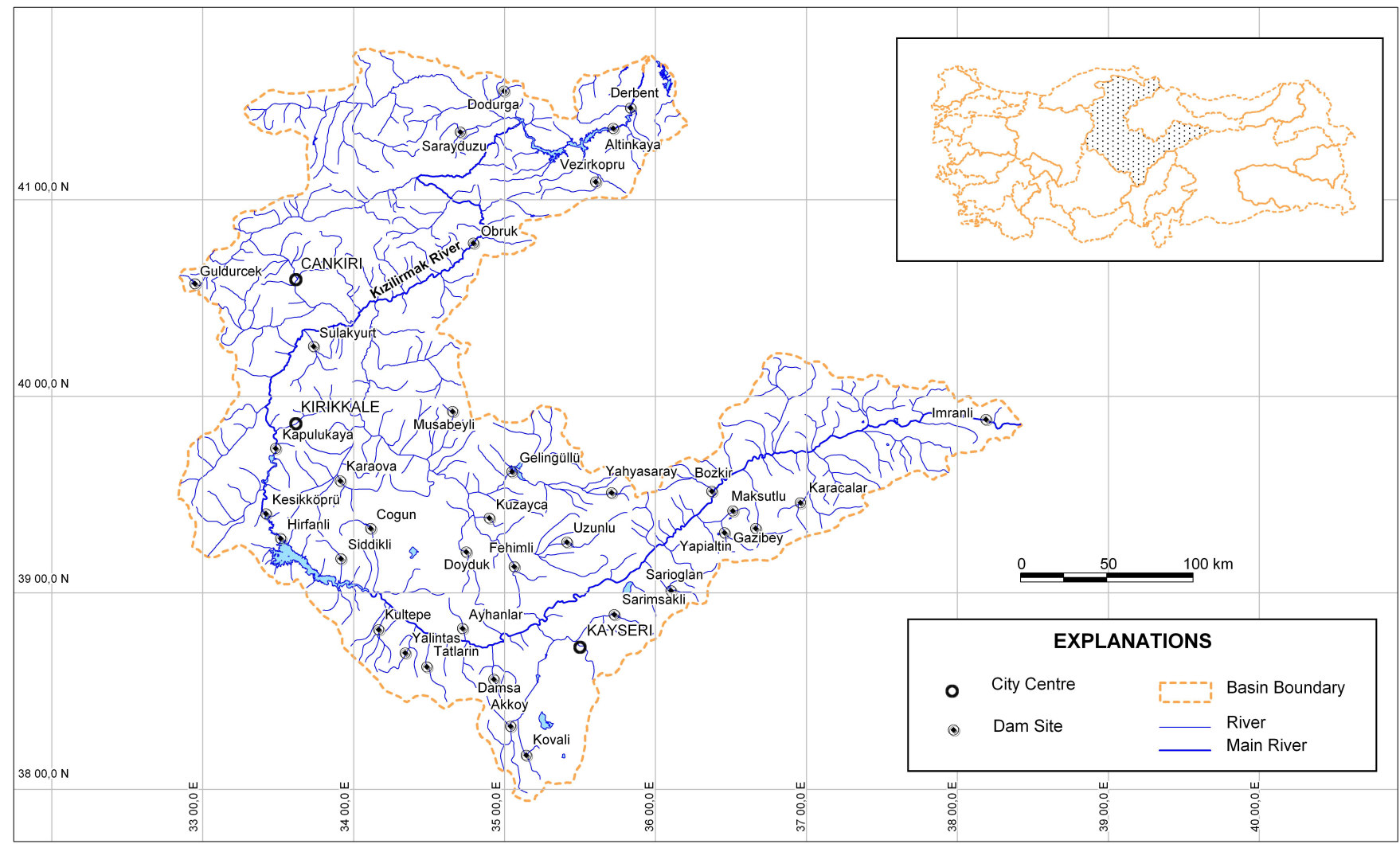

Fig. 1. The location of dams in the Kizilirmak Basin.

and flood control. These dams, which were planned and constructed by the State Hydraulic Works in Turkey, have a wide range, when considered their reservoir capacity and embankment volume. 31 of them have entirely been completed and five dams are still at construction stage in Kizilirmak river (Table 1).

This paper deals with an evaluation of seismic hazard and total risk, and evaluates 36 large embankment dams, which have a structural height ranging from 15 to $195 \mathrm{~m}$ in the Kizilirmak basin locating at the central part of Turkey.

\section{Seismo-tectonics model and seismic hazard of dam sites in the basin}

The recent studies performed for Kizilirmak basin indicate that the neotectonic of the basin is governed by four major elements: (1) the North Anatolian Fault (NAF), which is main structural feature in the basin, (2) the Ezinepazari Fault, which extends to west at south-west direction as a secondary feature of NAF, (3) the Ecemis Fault, which starts from Mediterranean Sea at the south and has approximately same direction with Ezinepazari fault. (4) Shear zone including secondary faults at the central part of basin.

The North Anatolian Fault is one of the best-known strikeslip faults in the world, because of its significant seismic ac- tivity and well developed surface features (Bozkurt, 2001). This zone produces very large earthquakes, which have resulted in the death of a thousand people and severe structural damages. The Ezinepazari fault, which is a secondary branch of NAF, has approximately $260 \mathrm{~km}$ length and extends to the central part of Anatolia at south-west direction. It is a strikeslip fault and its width can be defined by a single zone of a few hundred meters.

The Ecemis fault is also a strike-slip fault, which is located at the southern part of basin. It is composed of several fault segments and its width ranges from 2 to $15 \mathrm{~km}$. The shear zone, which is located from the central part to the southwest of Kizilirmak basin, includes so many structural features such as Kirsehir, Gumuskent, Delice, Akpinar and Bala faults. Figure 2 shows these faults systems on the national seismo-tectonic model.

For the seismic hazard analyses of the dam site in the basin, a detailed study was performed. Local geological features and seismic history were used to quantify the rate of seismic activity in the basin. As a result of detailed evaluation, total area covering all basins was separated into six seismic zones. Figure 3 introduces the seismic zones defined within the basin. The historical and recorded earthquake data shown in Fig. 3 was collected by the Bogazici University Kandilli Observatory and Earthquake Research Institute. 
Table 1. Properties of large dams considered for this study.

\begin{tabular}{|c|c|c|c|c|c|c|c|}
\hline Dam & River & Function* & $\begin{array}{l}\text { Completed } \\
\text { year** }\end{array}$ & Type*** & $\begin{array}{r}\text { Volume of } \\
\text { dam fill } \\
\left(\mathrm{hm}^{3}\right)\end{array}$ & $\begin{array}{r}\text { Height from } \\
\text { river bed } \\
(\mathrm{m})\end{array}$ & $\begin{array}{r}\text { Reservoir } \\
\text { capacity } \\
\left(\mathrm{hm}^{3}\right)\end{array}$ \\
\hline Akkoy & Asarcik & $\mathrm{I}+\mathrm{FC}$ & 1967 & $\mathrm{EF}$ & 0.430 & 42 & 7.54 \\
\hline ltinkaya & Kizilirmak & $\mathrm{E}$ & 1988 & RF & 15.900 & 195 & 5763.00 \\
\hline Ayhanlar & Kiziloz & I & 2003 & $\mathrm{EF}$ & 1.200 & 35 & 21.87 \\
\hline Bozkir & Hosur & $\mathrm{I}+\mathrm{FC}$ & 1982 & $\mathrm{RF}$ & 0.377 & 45 & 5.87 \\
\hline Cogun & Kilicozu & $\mathrm{I}+\mathrm{FC}$ & 1976 & $\mathrm{RF}$ & 0.455 & 28 & 23.05 \\
\hline Damsa & Damsa & $\mathrm{I}+\mathrm{FC}$ & 1971 & $\mathrm{EF}$ & 0.497 & 35 & 7.02 \\
\hline Derbent & Kizilirmak & $\mathrm{E}+\mathrm{I}$ & 1991 & RF & 2.500 & 29 & 213.00 \\
\hline Dodurga & Carşak & $\mathrm{I}+\mathrm{WS}$ & $\mathrm{u} / \mathrm{c}$ & $\mathrm{RF}$ & 0.508 & 51 & 8.44 \\
\hline Doyduk & Kalaycik & I & $\mathrm{u} / \mathrm{c}$ & $\mathrm{RF}$ & 3.400 & 41 & 68.11 \\
\hline Fehimli & Fehimli & I & 1986 & $\mathrm{EF}$ & 0.450 & 17 & 11.32 \\
\hline Gazibey & Osuguluc & $\mathrm{I}+\mathrm{FC}$ & 1992 & RF & 0.900 & 46 & 18.00 \\
\hline Gelingullu & Kanak & I & 1996 & $\mathrm{EF}$ & 1.362 & 44 & 272.35 \\
\hline Guldurcek & Yazi & I & 1988 & $\mathrm{EF}$ & 1.550 & 51 & 53.00 \\
\hline Hirfanli & Kizilirmak & $\mathrm{E}+\mathrm{FC}$ & 1959 & RF & 2.000 & 78 & 5980.00 \\
\hline Imranli & Kizilirmak & I & 2004 & $\mathrm{EF}$ & 1.800 & 46 & 62.50 \\
\hline Kapulukaya & Kizilirmak & $\mathrm{E}+\mathrm{WS}$ & 1989 & $\mathrm{EF}$ & 1.560 & 61 & 285.00 \\
\hline Karacalar & Karacalar & I & 2008 & $\mathrm{EF}$ & 0.900 & 33 & 49.00 \\
\hline Karaova & Manahozu & I & 1998 & $\mathrm{EF}$ & 2.300 & 49 & 65.00 \\
\hline Kesikkopru & Kizilirmak & $\mathrm{I}+\mathrm{E}$ & 1966 & RF & 0.900 & 49 & 95.00 \\
\hline Kovali & Dundarli & I & 1987 & $\mathrm{EF}$ & 2.994 & 42 & 25.10 \\
\hline Kuzayca & Kuzayca & I & 1985 & $\mathrm{EF}$ & 0.352 & 20 & 7.68 \\
\hline Kultepe & Koskerli & $\mathrm{I}+\mathrm{FC}$ & 1983 & $\mathrm{EF}$ & 1.200 & 37 & 25.25 \\
\hline Maksutlu & Maksutlu & I & 1982 & $\mathrm{EF}$ & 0.300 & 19 & 3.00 \\
\hline Musabeyli & Delicecayi Bisekozu & $\mathrm{I}+\mathrm{WS}$ & $\mathrm{u} / \mathrm{c}$ & $\mathrm{EF}$ & 2.740 & 61 & 48.60 \\
\hline Obruk & Kizilirmak & $\mathrm{I}+\mathrm{E}$ & 2007 & $\mathrm{EF}$ & 12.830 & 67 & 661.11 \\
\hline Sarayduzu & Asarcik & I & $\mathrm{u} / \mathrm{c}$ & $\mathrm{EF}$ & 2.020 & 59 & 33.08 \\
\hline Sarimsakli & Sarimsakli & $\mathrm{I}+\mathrm{FC}$ & 1968 & $\mathrm{EF}$ & 1.500 & 38 & 38.83 \\
\hline Sarioglan & Duzencik & I & $\mathrm{u} / \mathrm{c}$ & $\mathrm{EF}$ & 3.225 & 31 & 25.51 \\
\hline Siddikli & Korpeli Bogaz & I & 2001 & $\mathrm{RF}$ & 0.750 & 50 & 28.11 \\
\hline Sulakyurt & Suludere & I & 1980 & $\mathrm{RF}$ & 0.041 & 16 & 0.30 \\
\hline Tatlarin & Acisu & $\mathrm{I}+\mathrm{FC}$ & 1967 & $\mathrm{EF}$ & 0.200 & 34 & 2.21 \\
\hline Uzunlu & Kozanozu & $\mathrm{I}+\mathrm{FC}$ & 1996 & $\mathrm{EF}$ & 4.300 & 50 & 48.23 \\
\hline Vezirkopru & Istavroz & I & 2005 & RF & 2.570 & 73 & 51.47 \\
\hline Yahyasaray & Kanak & I & 1991 & $\mathrm{EF}$ & 1.100 & 47 & 17.86 \\
\hline Yalintas & Alacorakozu & I & 1997 & $\mathrm{EF}$ & 0.325 & 15 & 10.16 \\
\hline Yapialtin & Caylak & I & 1977 & $\mathrm{EF}$ & 1.000 & 30 & 14.60 \\
\hline
\end{tabular}

* E: Energy, I: Irrigation, FC: Flood control, WS: Water supply;

${ }^{* *} \mathrm{u} / \mathrm{c}$ : under construction;

*** RF: Rockfill, EF: Earthfill.

Throughout the study, seismic zones and earthquakes within the area having a radius of $100 \mathrm{~km}$ around the dam site were considered. Deterministic seismic hazard analysis was performed by the computer program DAMHA, which was developed at the Earthquake Research Center, Eskişehir Osmangazi University. Most of large dams in Turkey were analyzed by the authors in previous studies (Tosun and Seyrek, 2006, 2009; Tosun et al., 2007; Seyrek et al., 2009).
Due to the unavailability of strong motion records, various attenuation relationships were adopted to calculate the peak ground acceleration (PGA) acting on dam sites. For PGA calculations, five separate predictive relationships (Campbell, 1981; Boore et al., 1993, 1997; Gülkan and Kalkan, 2002; Ambraseys et al., 2005) were considered. 


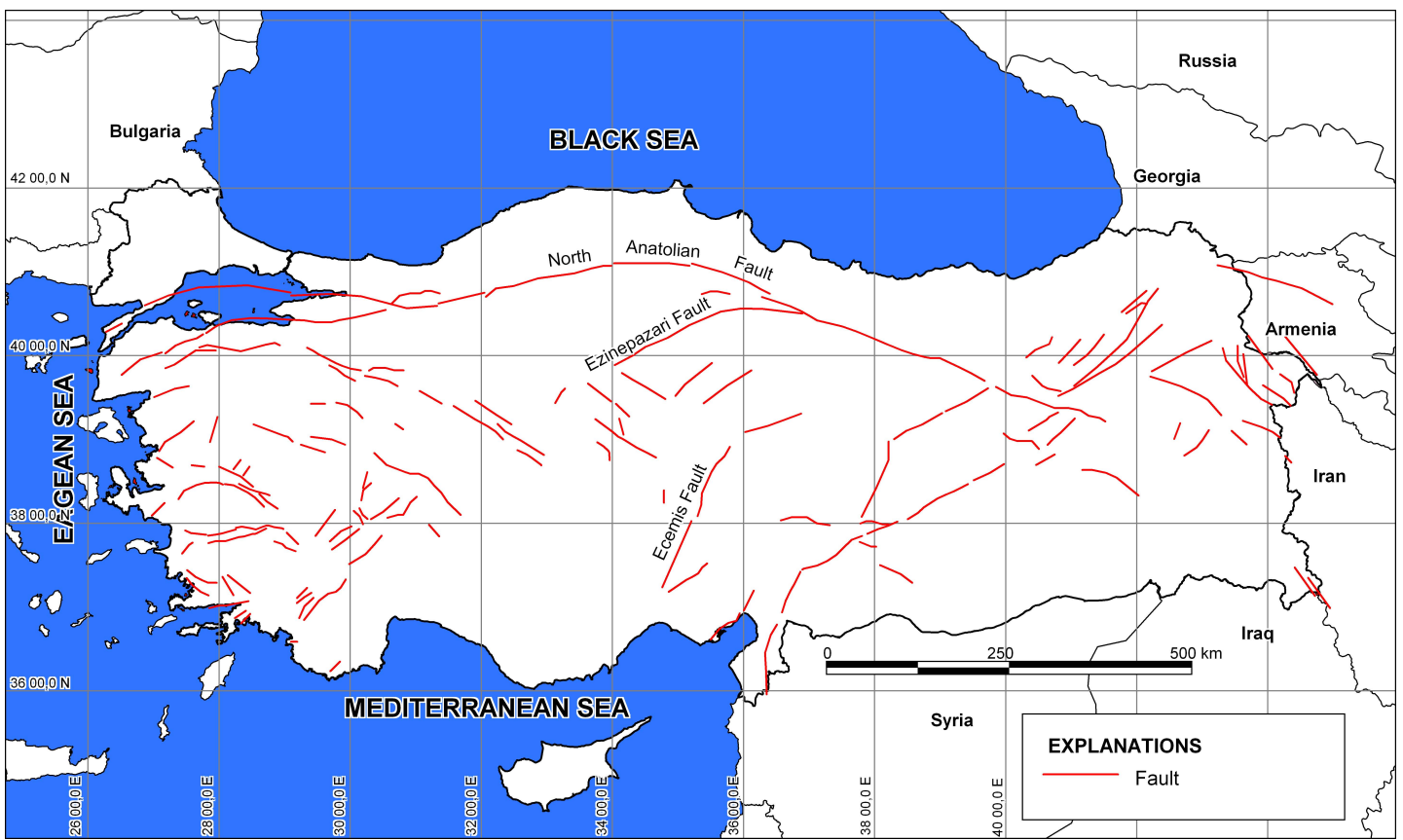

Fig. 2. Major structural elements of seismo-tectonic models of Turkey.

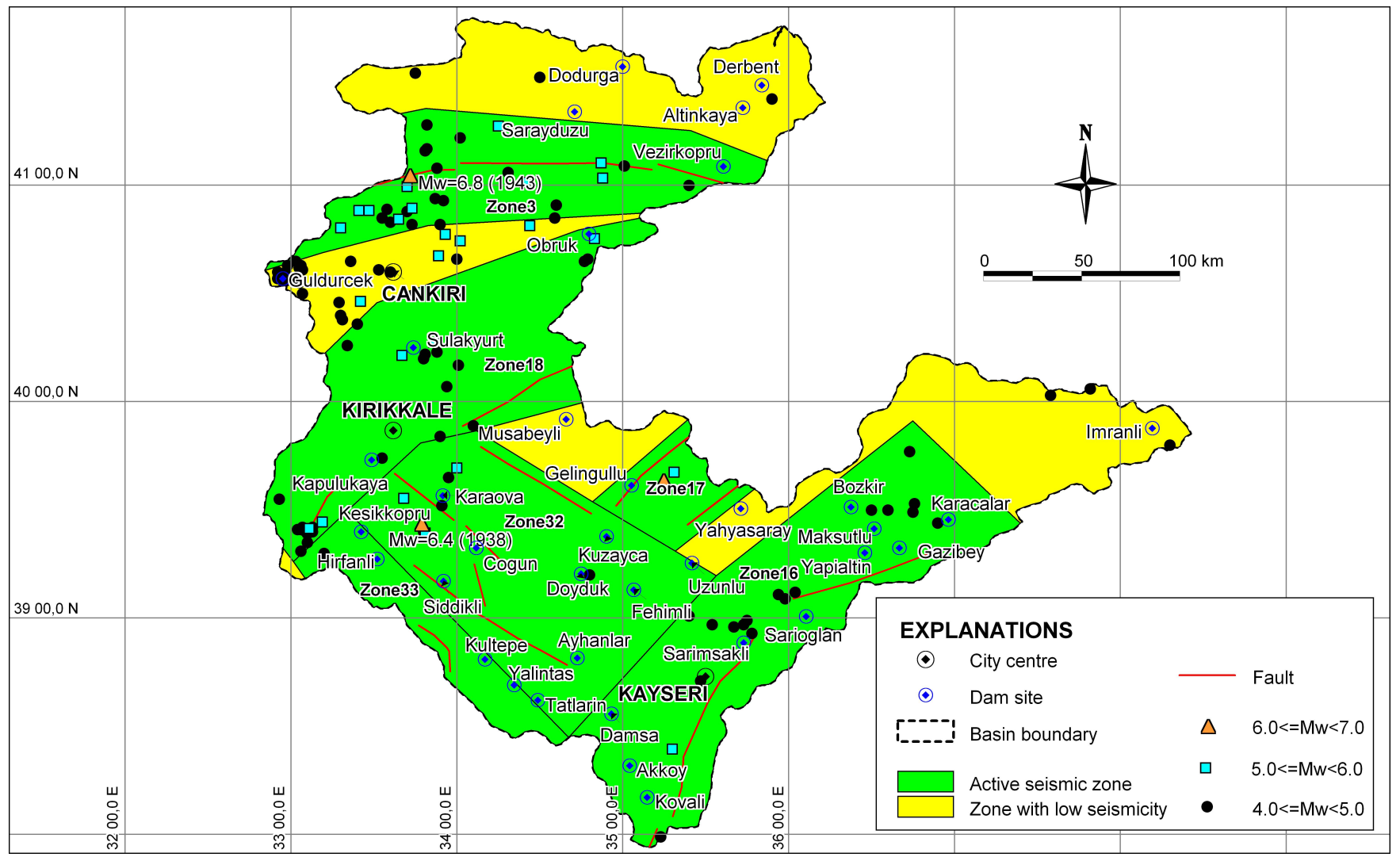

Fig. 3. Seismic zones and earthquakes occurred in the basin within last 100 years. 
Table 2. Summary of seismic hazard analyses performed for the large dams within the Kizilirmak Basin.

\begin{tabular}{lllrll}
\hline Dam & $M_{\text {maks* }} * \begin{array}{l}\text { PGA** } \\
\text { (g) }\end{array}$ & $\begin{array}{r}\text { Critical } \\
\text { zone }\end{array}$ & $\begin{array}{l}\text { Hazard } \\
\text { class }\end{array}$ & $\begin{array}{l}\text { Hazard } \\
\text { rating }\end{array}$ \\
\hline Akkoy & 7.4 & 0.15 & 16 & II & Moderate \\
Altinkaya & 7.4 & 0.11 & 3 & II & Moderate \\
Ayhanlar & 7.4 & 0.34 & 32 & IV & Extreme \\
Bozkir & 7.3 & 0.12 & 16 & II & Moderate \\
Cogun & 6.7 & 0.30 & 32 & IV & Extreme \\
Damsa & 7.4 & 0.12 & 32 & II & Moderate \\
Derbent & 7.4 & 0.09 & 3 & I & Low \\
Dodurga & 7.4 & 0.10 & 3 & II & Moderate \\
Doyduk & 7.2 & 0.12 & 32 & II & Moderate \\
Fehimli & 7.3 & 0.10 & 17 & II & Moderate \\
Gazibey & 7.3 & 0.32 & 16 & IV & Extreme \\
Gelingullu & 7.2 & 0.45 & 17 & IV & Extreme \\
Guldurcek & 7.7 & 0.14 & 3 & II & Moderate \\
Hirfanli & 7.4 & 0.20 & 32 & II & Moderate \\
Imranli & 7.8 & 0.20 & 3 & II & Moderate \\
Kapulukaya & 6.9 & 0.19 & 32 & II & Moderate \\
Karacalar & 7.3 & 0.20 & 16 & II & Moderate \\
Karaova & 6.9 & 0.29 & 32 & IV & Extreme \\
Kesikkopru & 7.4 & 0.14 & 32 & II & Moderate \\
Kovali & 7.4 & 0.22 & 16 & II & Moderate \\
Kuzayca & 7.2 & 0.21 & 32 & II & Moderate \\
Kultepe & 7.4 & 0.20 & 32 & II & Moderate \\
Maksutlu & 7.3 & 0.17 & 16 & II & Moderate \\
Musabeyli & 7.8 & 0.21 & 18 & II & Moderate \\
Obruk & 7.4 & 0.12 & 3 & II & Moderate \\
Sarayduzu & 7.4 & 0.16 & 3 & II & Moderate \\
Sarimsakli & 7.4 & 0.43 & 16 & IV & Extreme \\
Sarioglan & 7.3 & 0.26 & 16 & III & High \\
Siddikli & 7.4 & 0.42 & 32 & IV & Extreme \\
Sulakyurt & 7.8 & 0.14 & 18 & II & Moderate \\
Tatlarin & 7.4 & 0.17 & 32 & II & Moderate \\
Uzunlu & 7.3 & 0.18 & 17 & II & Moderate \\
Vezirkopru & 7.4 & 0.32 & 3 & III & Extreme \\
Yahyasaray & 7.3 & 0.26 & 17 & III & High \\
Yalintas & 7.4 & 0.17 & 32 & II & Moderate \\
Yapialtin & 7.3 & 0.26 & 16 & III & High \\
\hline & & & & & \\
\hline
\end{tabular}

* $M_{\max }$ : Earthquake magnitude calculated by Wells and Coppersmith (1994);

** PGA: Peak ground acceleration in g.

The deterministic seismic hazard analyses were performed for 36 dams in the basin. The results of analysis are given in Table 2 with other parameters for seismic hazard. Maximum earthquake magnitude was determined by using the empirical relationships proposed by Wells and Coppersmith (1994) as given in Table 3. It should be noted that each PGA value introduced for a dam site in this table means the average of those obtained from five separate attenuation relationships. The results indicate that PGA changes within a wide range as based on seismo-tectonic setting in basin.

As a result of seismic hazard analyses performed for the dams within the basin, the maps showing the equivalent PGA were developed by the MapInfo software (MapInfo, 2005) as
Table 3. Relationship between earthquake magnitude $\left(M_{\mathrm{W}}\right)$ and rupture length $(L)$.

\begin{tabular}{ll}
\hline Fault type & Equation \\
\hline Strike slip & $M_{\mathrm{W}}=5.16+1.12 \log L$ \\
Reverse & $M_{\mathrm{W}}=5.00+1.22 \log L$ \\
Normal & $M_{\mathrm{W}}=4.86+1.32 \log L$ \\
All & $M_{\mathrm{w}}=5.08+1.16 \log L$ \\
\hline
\end{tabular}

given in Fig. 4. The program is on the basis of Geographic Information System that is designed to work with spatially referenced data or geographic coordinates. For this study, 60 small dams or dams under the planning stage were also considered to obtain more realistic parameters to be used in seismic design of dam structures. Especially so many dam sites were taken into account as control points for the area including main structural features.

These maps show that the most critical area in the basin is very close to the North Anatolian Fault zone, because the greater acceleration values are seen on this part. This fault is critical for eight large dams considered for this study. They are Altinkaya, Derbent, Dodurga, Guldurcek, Imranli, Obruk, Sarayduzu and Vezirkopru dams. The estimated PGA values ranges from $0.09 \mathrm{~g}$ to $0.32 \mathrm{~g}$ for dams. There are also some isolated areas showing different seismological behavior. One of them and the most critical one is the area that includes the large dams of Gelingullu, Sarimsakli and Siddikli, and numerous small dams. The PGA values for these dams range from $0.42 \mathrm{~g}$ to $0.45 \mathrm{~g}$.

\section{Methods of analysis}

There are various methods to quantify the total risk factor of a dam. One of them, recommended by ICOLD (1989), considers the seismic hazard of the dam site and the risk rating of the structure separately. According to this method, the seismic hazard of the dam site regardless of type of dam can be classified into four groups from low to extreme. This is a quick way for rating the seismic hazard. The hazard class of a dam site obtained from this method provides a preliminary indication of seismic evaluation requirements.

ICOLD (1989) states that total risk of dams consists of structural and social-economics components. The first one is mainly based on the capacity of the reservoir and the height of dam. The second one is based on the evacuation requirement and potential downstream damage. The total risk factor is defined as a summation of risk factors for capacity, height, evacuation requirements and potential damage. Based on the total risk factor, four risk classes are defined as low, moderate, high or extreme. Risk classification of a dam provides more detailed information for the selection of seismic evaluation parameters and methods to be used for analysis. 


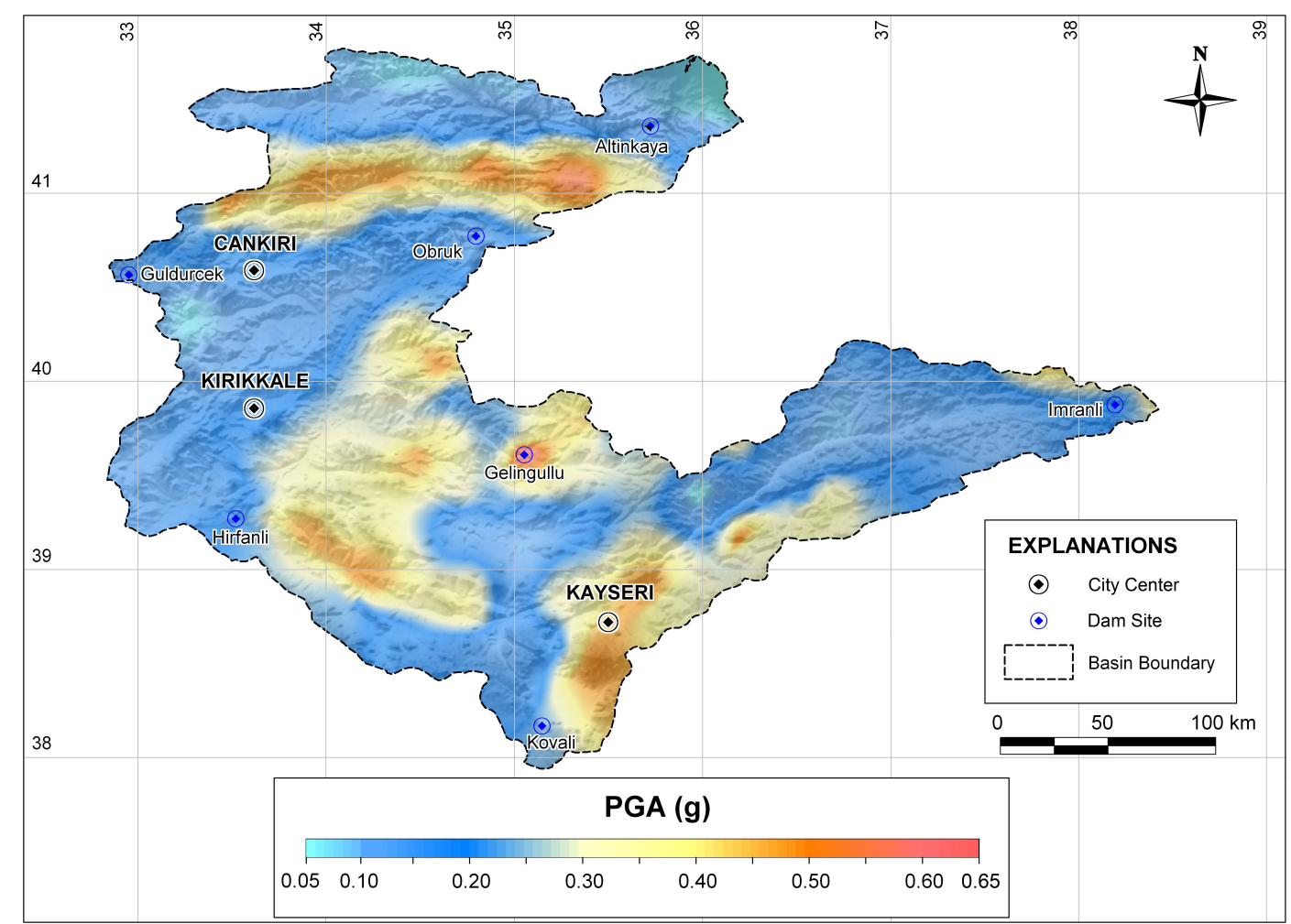

Fig. 4. Seismic hazard map of the Kizilirmak Basin as based on maximum design earthquake which represents a dam site.

It should be noted that special considerations for safety are recommended for large dams having a height above $90 \mathrm{~m}$ and a storage capacity greater than $1200 \mathrm{hm}^{3}$.

Bureau method considers various risk factors and weighting points to quantify the total risk factor (TRF) of any dam. Bureau (2003) states that TRF depends on the dam type, age, size, downstream risk and vulnerability, which depends on the seismic hazard of the site as given in Eq. (1).

$\mathrm{TRF}=[(\mathrm{CRF}+\mathrm{HRF}+\mathrm{ARF})+\mathrm{DHF}] \cdot \mathrm{PDF}$

Where CRF is risk factor of capacity; HRF is risk factor of height; ARF is age rating factor; DHF is downstream hazard factor; and PDF is predicted damage factor. Three factors (CRF+HRF+ARF) quantify the risk of a dam and its reservoir. Structure influence on this equation is represented by their summation. The downstream hazard factor (DHF) is based on population and property at risk, and defined as a function of two different factors (Eq. 2).

$\mathrm{DHF}=\mathrm{ERF}+\mathrm{DRI}$

Where ERF is evacuation requirement factor and DRI is downstream damage risk index. The factor of downstream evacuation requirements (ERF) depends on the human population at risk. The downstream damage risk index is based on the value of private, commercial, industrial of government properties in the potential flood path. The values of all factors can be obtained from Bureau (2003).
The vulnerability rating represents the site-dependent seismic hazard, as defined by a predicted damage factor (PDF). It is assigned to each dam as given in the Eq. (3). In this equation PDI is the predicted damage index and calculated from the dam vulnerability curves developed by Bureau and Ballentine (2002). PDI depends on the dam type and site seismic hazard, and calculated as a function of earthquake severity index (ESI), which represents the expected ground motion at the dam site for the scenario earthquake considered, as given in Eq. (4).

$\mathrm{PDF}=2.5 \cdot \mathrm{PDI}$

$\mathrm{ESI}=\mathrm{PGA} \cdot(M-4.5)^{3}$

Where PDI is potential damage index; PGA is peak ground acceleration in $\mathrm{g}$; and $M$ is the Richter or moment magnitude.

\section{Total risk analyses and discussions}

The total risk for dam structures mainly depends on the seismic hazard rating of dam site and the risk rating of the dam structure. The Bureau (2003) method, which considers dam type, age, size, downstream damage potential and evacuation requirements, was utilized to realize the risk analyses of basin. It recommends four separate risk classes ranging from I (low risk) to IV (extreme risk) as based on the Total 
Table 4. Summary of total risk analyses performed for the large dams within the Kizilirmak Basin.

\begin{tabular}{|c|c|c|c|c|c|c|c|c|c|c|}
\hline \multirow[b]{2}{*}{ Dam } & \multicolumn{2}{|c|}{ Site influence ${ }^{(*)}$} & \multicolumn{3}{|c|}{ Structure influence ${ }^{(* *)}$} & \multicolumn{2}{|c|}{ Downstream influence ${ }^{(* * *)}$} & \multirow[b]{2}{*}{$\operatorname{TRF}^{(* * * *)}$} & \multirow[b]{2}{*}{ Risk class } & \multirow[b]{2}{*}{ Definiton } \\
\hline & $M_{\max }$ & PGA & $\mathrm{CRF}$ & $\mathrm{HRF}$ & $\mathrm{ARF}$ & DRI & ERF & & & \\
\hline Akkoy & 7.4 & 0.15 & 4 & 6 & 3 & 4 & 8 & 137.9 & III & High \\
\hline Altinkaya & 7.4 & 0.11 & 6 & 6 & 2 & 12 & 12 & 144.6 & III & High \\
\hline Ayhanlar & 7.4 & 0.34 & 4 & 6 & 1 & 8 & 8 & 158.7 & III & High \\
\hline Bozkir & 7.3 & 0.12 & 4 & 6 & 2 & 8 & 12 & 121.4 & II & Moderate \\
\hline Cogun & 6.7 & 0.30 & 4 & 6 & 2 & 4 & 8 & 93.4 & II & Moderate \\
\hline Damsa & 7.7 & 0.12 & 4 & 6 & 3 & 8 & 4 & 138.7 & III & High \\
\hline Derbent & 7.4 & 0.09 & 6 & 6 & 2 & 12 & 12 & 140.8 & III & High \\
\hline Dodurga & 7.4 & 0.10 & 4 & 6 & 1 & 8 & 4 & 86.4 & II & Moderate \\
\hline Doyduk & 7.2 & 0.12 & 6 & 6 & 1 & 4 & 8 & 93.5 & II & Moderate \\
\hline Fehimli & 7.3 & 0.10 & 4 & 4 & 2 & 4 & 4 & 95.2 & II & Moderate \\
\hline Gazibey & 7.3 & 0.32 & 4 & 6 & 2 & 8 & 12 & 137.1 & III & High \\
\hline Gelingullu & 7.2 & 0.45 & 6 & 6 & 2 & 12 & 12 & 224.5 & III & High \\
\hline Guldurcek & 7.7 & 0.14 & 4 & 6 & 2 & 12 & 12 & 202.2 & III & High \\
\hline Hirfanli & 7.4 & 0.20 & 6 & 6 & 3 & 12 & 12 & 160.0 & III & High \\
\hline Imranli & 7.8 & 0.20 & 6 & 6 & 1 & 8 & 8 & 168.7 & III & High \\
\hline Kapulukaya & 6.9 & 0.19 & 6 & 6 & 2 & 12 & 12 & 182.5 & III & High \\
\hline Karacalar & 7.3 & 0.20 & 4 & 6 & 1 & 4 & 4 & 151.1 & III & High \\
\hline Karaova & 6.9 & 0.29 & 6 & 6 & 2 & 8 & 8 & 144.5 & III & High \\
\hline Kesikkopru & 7.4 & 0.14 & 6 & 6 & 3 & 8 & 8 & 121.7 & II & Moderate \\
\hline Kovali & 7.4 & 0.22 & 4 & 6 & 2 & 4 & 8 & 136.4 & III & High \\
\hline Kuzayca & 7.2 & 0.21 & 4 & 4 & 2 & 4 & 4 & 122.5 & II & Moderate \\
\hline Kultepe & 7.4 & 0.20 & 4 & 6 & 2 & 4 & 8 & 112.9 & II & Moderate \\
\hline Maksutlu & 7.3 & 0.17 & 4 & 4 & 2 & 4 & 4 & 121.5 & II & Moderate \\
\hline Musabeyli & 7.8 & 0.21 & 4 & 6 & 1 & 12 & 12 & 157.6 & III & High \\
\hline Obruk & 7.4 & 0.12 & 6 & 6 & 1 & 12 & 12 & 200.4 & III & High \\
\hline Sarayduzu & 7.4 & 0.16 & 4 & 6 & 1 & 8 & 8 & 171.9 & III & High \\
\hline Sarimsakli & 7.4 & 0.43 & 4 & 6 & 3 & 8 & 12 & 173.5 & III & High \\
\hline Sarioglan & 7.3 & 0.26 & 4 & 6 & 1 & 4 & 8 & 154.2 & III & High \\
\hline Siddikli & 7.4 & 0.42 & 4 & 6 & 1 & 4 & 8 & 102.9 & II & Moderate \\
\hline Sulakyurt & 7.8 & 0.14 & 2 & 4 & 2 & 1 & 4 & 70.0 & II & Moderate \\
\hline Tatlarin & 7.4 & 0.17 & 4 & 6 & 3 & 8 & 8 & 139.3 & III & High \\
\hline Uzunlu & 7.3 & 0.18 & 4 & 6 & 2 & 8 & 12 & 155.4 & III & High \\
\hline Vezirkopru & 7.4 & 0.32 & 4 & 6 & 1 & 12 & 12 & 151.8 & III & High \\
\hline Yahyasaray & 7.3 & 0.26 & 4 & 6 & 2 & 4 & 8 & 160.0 & III & High \\
\hline Yalintas & 7.4 & 0.17 & 4 & 4 & 2 & 1 & 4 & 105.8 & II & Moderate \\
\hline Yapialtin & 7.3 & 0.26 & 4 & 6 & 2 & 4 & 8 & 114.2 & II & Moderate \\
\hline
\end{tabular}

* $M_{\max }$ : Earthquake magnitude calculated by Wells and Coppersmith (1994) PGA: Peak ground acceleration in g;

** CRF: Capacity risk factor, HRF: Height risk factor, ARF: Age risk factor;

$* * *$ DRI: Downstream damage risk index, ERF: Evacuation requirements factor;

**** TRF: Total risk factor.

Risk Factor (TRF). If the TRF is between 2 and 25, the risk class of dam is I (low). If the TRF is ranging from 25 to 125 and from 125 to 250, the risk classes of dam is II (moderate) and III (high), respectively. If the TRF is greater than 250 , the risk class of dam is IV (extreme). Following Bureau's method, all large dams in the basin are classified in risk classes II and III, a moderate and high risk rating. The solution obtained from Bureau method is more rational than those estimated by ICOLD method.
The results of total risk analyses of the dam within the Kizilirmak basin are totally given in Table 4 . The values of the TRF range from 70.0 to 224.5 . This means that there is no dam having a risk classes IV and I in the basin. There are thirteen dams of a risk class II and twenty-three dams of a risk class III. In other words, $64 \%$ of total dams are identified approximately as a risk class III, while the rest are identified as class II (Table 4). 
Dams having a high-risk class are concentrated on the Northern part of the basin. In other word, the dams, which are under the impact of North Anatolian fault system, have high-risk potential. The dams, which are classified as risk class II with moderate risk rating, are mainly concentrated on the central part of basin and have entirely been constructed on the secondary branches of Kizilirmak river.

This study identified at least twenty-three large dams of the Kizilirmak basin, which must be reanalyzed by selecting appropriate seismic parameters. For some dams, seismic hazard analyses should be renewed before total risk and dynamic analyses. They are Altinkaya, Derbent, Guldurcek, Hirfanli, Kapulukaya, Kesikkopru and Vezirkopru dams. Rehabilitation design and construction measures, if necessary, may follow after in cases where the dams are found deficient seismically. Gellingullu, Sarimsakli and Siddikli dams should especially be reanalyzed seismically by probabilistic analyzing method, while considering local attenuation relationships of dam sites.

Altinkaya dam is the highest structure with a height of $195 \mathrm{~m}$ from the river bed and has the largest reservoir with $5763 \mathrm{hm}^{3}$ in the basin. Its construction was started in 1980 and entirely completed in 1988. It was designed just to produce electricity of $1662 \mathrm{GWh}$ per year with an installed capacity of $700 \mathrm{MW}$. Its TRF value is 144.6, and it is identified as risk class III with high risk rating. According to the seismic hazard analyses of this study, it will be subjected to a peak ground acceleration of $0.11 \mathrm{~g}$ with an earthquake magnitude of 7.4. It seems safe for earthquake conditions as a result of pseudo-static analyses.

The Hirfanli dam is a zoned rockfill dam on the main Kizilirmak river near Kaman County, located $45 \mathrm{~km}$ northwest of Kirsehir city. It has a 78-m height from river bed. When the reservoir is at normal capacity, the facility impounds $5980 \mathrm{hm}^{3}$ of water with a reservoir surface area of $263 \mathrm{~km}^{2}$. Its construction began in 1953 and was finished in 1959. It was designed to produce electricity of $400 \mathrm{GWh}$ per year with an installed capacity of $128 \mathrm{MW}$. Its reservoir is also used for water supply of Ankara city as a spare source. This 51-years old rockfill dam is in excellent condition, but it cannot meet current seismic design standards. Therefore its seismic upgrade should be provided as soon.

Kapulukaya dam is a 61.0-m high earthfill dam, with a total embankment volume of $1560000 \mathrm{~m}^{3}$. It is located $12 \mathrm{~km}$ south of the Kirikkale city and on the main Kizilirmak River. Its construction was started in 1979 and finished in 1989. When the reservoir is operated with normal water level, the facility approximately impounds $285 \mathrm{hm}^{3}$ of water with a reservoir surface area of $20.7 \mathrm{~km}^{2}$. It supplies water for city and industry usage. It is also designed to produce electricity of $190 \mathrm{GWh}$ per year with an installed capacity of $54 \mathrm{MW}$. The seismic hazard analyses performed throughout this study indicates that Kapulukaya dam can be one of the critical dams within the basin. It will be subjected to a peak ground acceleration of $0.19 \mathrm{~g}$ with an earthquake magnitude of 6.9 It is also classified into the risk class III with high risk. Seismic deformation analyses should be performed for Kapulukaya dam, because of the relatively low factors of safety obtained in the pseduo-static analyses.

The Obruk dam is a earthfill dam on the main Kizilirmak river, which is located $30 \mathrm{~km}$ south-east of Corum city. It has a 67-m height from river bed and a huge embankment volume $\left(12830000 \mathrm{~m}^{3}\right)$. When the reservoir is at normal capacity, the facility impounds $611 \mathrm{hm}^{3}$ of water with a reservoir surface area of $50 \mathrm{~km}^{2}$. Its construction started in 1996 and was entirely completed in 2007 . It was designed to produce electricity of $473 \mathrm{GWh}$ per year with an installed capacity of $203 \mathrm{MW}$. Its reservoir is also used for irrigating land of 7179 ha in the region. It will be subjected to relatively low PGA value $(0.12 \mathrm{~g})$ with an earthquake magnitude of 7.4. But it is classified into the risk class III with high risk rating. A detail seismic hazard and risk analyses including dynamic stability should be performed for Obruk dam, because of having a close location to the North Anatolian Fault System.

\section{Conclusions}

Through the seismic hazard and total risk analyses performed for thirty-six large dams in Kizilirmak basin, the following results have been concluded:

1. The dams, which are classified as risk class II with moderate risk rating, are mainly concentrated on the central part of basin and have been constructed on the secondary branches of Kizilirmak river. The dams having a high-risk potential (risk class III) are generally under impact of the North Anatolian fault system.

2. Most of the dams, which were located near active seismic zone, have damaged or failed during earthquakes. The most well-known earthquake damage to an embankment dam occurred in Turkey during the 1986 Dogansehir earthquake with $M_{\mathrm{s}}$ of 5.8. The epicenter of earthquake was very close to Surgu dam and the damages to the structure were a result of the strong motion of the nearby fault. In the Kizilirmak basin, there is a shear zone, which was frequently jointed, fractured and faulted at the south part of basin where the Gelingullu, Sarimsakli and Siddikli dams are located. The PGA values range from $0.42 \mathrm{~g}$ to $0.45 \mathrm{~g}$ (extreme hazard classes) for these dams. A damage or failure risk is high for these dams, when subjected to a loading of an earthquake with high magnitude. The authors state that all dams within the shear zone of basin are under the influence of local near-source zone and their seismic positions must be re-evaluated in detail with a special concept. 
3. This study clearly indicates that at least 23 large dams of the Kizilirmak basin have a high total risk. Most of them are old dams that their age rises up to 40 years. For these dams, seismic hazard analyses should be performed by deterministic and probabilistic methods with considering the national seismo-tectonic model before executing the conventional static and the sophisticated dynamic analyses. Rehabilitation design and construction measures, if necessary, may follow after in cases where the dams are found deficient seismically.

4. Altinkaya, Hirfanli, Kapulukaya and Obruk dams, which are identified as risk class III with high risk were mainly designed for producing electricity. They have large reservoirs on the main river and are under operation stages. Therefore, these dams have an important role in the Turkish economy and provide a high risk for downstream life. Hirfanli and Kapulukaya dams also have water supply function for Ankara and Kirikkale cities in where at least four million people are living. These dams must be analyzed with high priority and redesigned to increase the safety of the embankments and their appurtenant structures, if necessary.

Acknowledgements. Authors are thankful to the authorities of the State Hydraulic Works for their cooperation in the research and providing the necessary data.

Edited by: L. Ferraris

Reviewed by: two anonymous referees

\section{References}

Ambraseys, N. N., Douglas, J., Karma, S. K., and Smit, P. M.: Equations for the estimation of strong ground motions from shallow crustal earthquakes using data from Europe and the Middle East: horizontal peak ground acceleration and spectral acceleration, B. Earthq. Eng., 3, 1-53, 2005.

Boore, D. M., Joyner, W. B., and Fumal, T. E.: Estimation of response spectra and peak accelerations from Western North American Earthquakes: An interim report, US Geol. Surv. Open-File Rept. 93-509, 72 pp., 1993.

Boore, D. M., Joyner, W. B., and Fumal, T. E.: Equations for estimating horizontal response spectra and peak acceleration from Western North American earthquakes: A summary of recent work, Seismol. Res. Lett., 68, 128-153, 1997.

Bozkurt, E.: Neotectonics of Turkey-a Synthesis, Geodin. Acta, 14, 3-30, 2001.
Bureau, G. J. and Ballentine, G. D.: A comprehensive seismic vulnerability and loss assessment of the State of South Carolina using HAZUS. Part VI. Dam inventory and vulnerability assessment methodology. 7 th National Conference on Earthquake Engineering, July 21-25, Boston, Earthquake Engineering Research Institute, Oakland, CA, 2002.

Bureau, G. J.: Dams and Appurtenant Facilities in Earthquake Engineering Handbook, edited by Chenh, W. F. and Scawthorn, C., CRS press, Bora Raton 26.1-26.47, 2003.

Campbell, K. W.: Near-source attenuation of peak horizontal acceleration, B. Seismol. Soc. Am., 71(6), 2039-2070, 1981.

Castro, G., Poulos, S. J., and Leathers, F.: Re-examination of Slide of Lower San Fernando Dam, J. Geotech. Eng.-ASCE, 111(9), 1093-1107, 1985.

Erdik, M., Doyuran, V., Gülkan, P., and Akkaş, N.: Evaluation of Earthquake Hazard in Turkey with Statistical Approach, Middle East Technical University Earthquake Engineering Research Center, Ankara, 116 pp., 1985 (in Turkish).

Gülkan, P. and Kalkan, E.:Attenuation modeling of recent earthquakes in Turkey, J. Seismol., 6(3), 397-409, 2002.

ICOLD: Selecting seismic parameters for large dams- guidelines and recommendations: ICOLD Committee on Seismic Aspects of Dams Design, Bulletin, 72, 36 pp., 1989.

Jansen, R. B. (Ed.): Advanced dam engineering for design, construction and rehabilitation. Van Noswtrand Reinhold, New York, 884 pp., 1988.

Seed, H. B., Lee, K. L., and Idriss, I. M.: Analysis of Sheffield Dam failure. Journal of Soil Mechanics and Foundations-ASCE, 95(SM6), 1453-1490, November 1969.

Seed, H. B., Lee, K. L., Idriss, I. M., and Makdisi, F. I.: The slides in the San Fernando Dams during the Earthquake of February 9, 1971, J. Geotech. Eng.-ASCE, 101(GT7), 651-688, 1975.

Seyrek, E., Orhan, A., and Tosun, H.: Deterministic seismic hazard analysis of dams in Ceyhan basin, Second National Symposium on Dam safety with International Participation, Eskişehir, Turkey, 575-582, 2009 (in Turkish).

Tosun, H.: Earthquake-resistant design for embankment dams, Publication of General Directorate of State Hydraulic Works, Ankara, 208 pp., 2002 (in Turkish).

Tosun, H. and Seyrek, E.: Seismic studies on Turkish dams, International Water Power\&Dam Construction, 20-23, February 2006.

Tosun, H., Zorluer, İ., Orhan, A., Seyrek E., Türköz, M., and Savaş, H.: Seismic hazard and total risk analyses for large dams in Euphrates Basin in Turkey, Eng. Geol., 89(1-2), 155-170, 2007.

Tosun, H. and Seyrek, E.: Total risk analysis of concrete dams in Turkey, Second National Symposium on Dam safety with International Participation, Eskişehir, Turkey, 567-574, 2009 (in Turkish). 